\title{
Religious Change among the Kore: Politics and Christianity in Southwestern Ethiopia
}

\author{
Awoke Amzaye Assoma \\ Department of Anthropology, Washington State University, USA
}

Copyright $(2016$ by authors, all rights reserved. Authors agree that this article remains permanently open access under the terms of the Creative Commons Attribution License 4.0 International License

\begin{abstract}
Although the introduction of Christianity to the Kore, southwestern Ethiopia, dates to the $14^{\text {th }}$ and $15^{\text {th }}$ centuries, it remained marginal until Charismatic-Pentecost al Christianity expanded and transformed the religious landscape of the Kore in the $20^{\text {th }}$ century. This paper explores the historical and political factors behind this surge and its effects on Kore culture and belief. Based on literature review and my field observations, I argue that the religious change in Kore reflects historically varying counter-hegemonic reactions to north Ethiopian domination. Contemporary religious change, the paper will show, needs to be understood as counter-hegemonic reaction capable of reorganizing the Kore culture and belief in particular and the communities of southwestern Ethiopia in general.
\end{abstract}

Keywords Kore, Ethiopia, Charismatic-pentecostal Christianity, Counter-hegemonic Reaction

\section{Introduction}

This paper explores a rapid religious transformation, within less than half a century, among the Kore community, southwestern Ethiopia. The Kore are an Omotic speaking people with a population of 156, 983 in 2007 [1]. The Kore are primarily semi-subsistent agriculturalists who rely heavily upon enset (Ensete ventricosum). Before the end of the nineteenth century, Kore was an independent Omotic kingdom. The Ethiopian Empire annexed and incorporated the Kore kingdom in 1896 [2]. The divine Kore king, King Amole, was conquered, imprisoned, and later died in prison. The conquerors demolished traditional sacred places and shrines; imprisoned and humiliated diviners and shamans. They forced the Kore to quit their traditional religion and accept Orthodox Christianity. Nevertheless, the Kore would not accept the religion that came with and preached by the conquerors; so, attempts to convert the Kore to Ethiopian Orthodox Christianity had little success. Therefore, the Kore maintained their traditional beliefs until the1980s.

This paper is an ethnographic and historical exploration of the rapid expansion of Charismatic-Pentecostal Christianity among the Kore people of southwestern Ethiopia and its effects on Kore culture and belief. I seek to answer two questions about the expansion of Charismatic-Pentecostal Christianity in Kore. (1) What historical situations enabled the rapid expansion of Charismatic-Pentecostal Christianity in Kore? (2) What are the impacts of this rapid expansion of Charismatic-Pentecostal Christianity on the Kore culture and how does this relate to other African Charismatic-Pentecostal movements? Anthropological writings on Christianity emphasize the 'utilitarian' and 'intellectualist' 1 approaches to explain why people are attracted to one or another form of religion [3, 4]. In addition to these, I argue, religious change reflects historically varying reactions to domination. By exemplifying the Kore case, this paper will show that contemporary religious change among the Kore in particular and southwestern Ethiopian in general needs to be understood as a counter-hegemonic reaction capable of reorganizing the cultures and belief systems of these societies. By illuminating politico-historical reasons for rapid expansion of Charismatic-Pentecostal Christianity among the Kore, this paper aims to furthering our understanding of the relations between religion, history, and politics in contemporary Ethiopian society.

\section{Review of Literature}

The Kore is one of the least studied Ethiopian groups. Cerulli [5], Haberland [6], Huntingford [7], Levin [8], Bender [9], and Fleming [10] give passing remarks mainly on linguistic categorization of Kore language. Although not particularly on the Kore, Donham and James [11] and Donham [12] made valuable investigation on the history, political economy, and the expansion of imperial Ethiopia to the peripheral and marginalized peoples of southwestern Ethiopia. In this regard, Sato [13] shows how this expansion

\footnotetext{
${ }^{1}$ According to Keller [3: p.6] 'the 'utilitarian' approach, emphasizes the expectation of worldly advantages through conversion, and the 'intellectualist' approach, emphasizes 'converts' search for meaning in a changing world'.
} 
helped the people of Majangir to organize themselves and struggle to reclaim land they lost to the Ethiopian government. Christianity plays a crucial role in the politics of Ethiopia [14, 15] because, as Abbink [16: p. 253] reports, 'religious identities are becoming more dominant as people's primary public identity' in Ethiopia. The expansion of Protestant and Charismatic-Pentecostals has been used to challenge the hegemony of Ethiopian Orthodox Christianity. Thus, although the Ethiopian Orthodox Church used to be a dominant influence in the Ethiopian government, the rapid expansion of Charismatic-Pentecostal Christianity has forced the Ethiopian Orthodox Church to reform itself to sustain, if not to increase, its current position in the religious landscape of Ethiopia [17].

Generally, besides these anthropological-historical works, there are some works mainly concerned with success stories of various missionary groups [18-22]. These writings also have important sections on political and historical developments in southwestern Ethiopia. These literatures [13, 17, 21-25] emphasize three general historical and political developments. The first is the incorporation of the peoples of southwestern Ethiopia into the Ethiopian Empire state in the 19th century. The second is the1974 Ethiopian Revolution that resulted in the ousting of Emperor Haile Selassie I and the establishment of a military communist regime called the derg [22]. The third development is the overthrow of the military regime by two groups of guerrilla fighters, the Eritrean People Liberation Front (EPLF) and the Tigrian People Liberation Front (TPLF), in 1991.

\section{Methods}

This ethnographic and historical paper draws primarily on anthropological and non-anthropological literature, government/non-government census reports and my personal field observation among the Kore people. In 1985, I undertook research among the Kore and wrote my undergraduate thesis on the history of the Kore; since then I remained in touch with the area. Meantime, in May 28-30, 2011, I attended the Kore Culture and Language Symposium. The symposium focused on assessing alternative options that could revitalize and strengthen Kore language (including how to expand and strengthen Kore language education in schools) ${ }^{2}$ and culture. During this visit to Kore, I was able to observe the number of churches in and around Kele Town (the capital of Amaro district), their location, and community church services. This initiated my research on Kore Christianity. Much of my research relied on participant observation and interviews. I interviewed eighty people including church leaders, pastors, new and old converts to Charismatic-Pentecostal Churches; my interview focused on history of Christianity among the Kore, theology and organizational structures, experiences of converts ('testimony' narrative interviews), and how and why

\footnotetext{
${ }^{2}$ Kore language (Koorete) is one subject in all schools of Korso from grade $1-4$ since the last 15 or so years.
}

Charismatic-Pentecostal Christianity got so many adherents in such a short period. I supplemented the interview by personal participant observations during my three months (one month each year) visit to Kele in July/August 2012, 2013, and 2014. I participated in different public meetings, bible study programs, prayer groups, and church and house worship programs. Generally, my previous experience and knowledge of the Kore people and Kore language (Koorete) enabled me to understand the conversations. I also consulted published and unpublished written resources.

\section{Christianity among the Kore}

\subsection{The Imperial Era}

Many researchers [11, 26-27] report that there were traces of Orthodox Christianity in southern Ethiopia before the sixteenth century. According to Kore oral tradition, the Kore emigrated from Manz in Shawa (central Ethiopia) via Kafa, Dawuro and Gamo Gofa between the end of the fourteenth century and the beginning of the fifteenth century. These emigrants, who carried Tabots (replicas of the Arc of the Covenant) with them, founded some Orthodox churches including Yero Medhane Alem, Icha Giorgis, and Derba Michael churches in Amaro. However, an Islamic holy warrior named Ahmed Gragn, a sultan from Harar, eastern Ethiopia [28], invaded highland Christian Abyssinia in the $16^{\text {th }}$ century and burned all the churches and persecuted Christians; the persecution forced the remaining few Kore Christians and priests to flee to Birbir Mariam, in Gamo, and other places. Eventually, the Kore relapsed to their traditional beliefs and remained so until Orthodox Christianity was reintroduced in the $19^{\text {th }}$ century; i.e., until the Ethiopian Empire annexed and incorporated the Kore in $1896[2,29]$.

The annexation reduced the Kore to subalternity [2]. There was widespread feeling that conversion to Orthodox Christianity would only confirm this status. As one informant recalls,

If a Kore was not Orthodox Christian, he was considered as unbeliever and backward. The Qawe $^{3}$ who did not understand what we Kores speak named our language bird's language, not intelligible. Of course, even in the 1960s, when I went to Kele [district town] elementary school, speaking Kore language in schools was forbidden. On the other hand, the Kore were not willing to change to Orthodox Christianity because the Kore perceived Orthodox Christianity and the Ethiopian oppressive system as two sides of the same coin (Awoke. Personal comm. with informant ${ }^{4} .2013$ July 23).

\footnotetext{
3 Qawe is a Kore word for the ruling 'Amhara' ethnic group. Of course, qawe is a generic word for the ruling elite who came from outside of Amaro. This ruling elite could come from Amhara, Tigray, Oromo, and even Kore ethnic groups.

${ }^{4}$ Informant names not mentioned for safety reasons.
} 
Generally, the Ethiopian Orthodox Church was coercive and forced people to covert. Moreover, the Ethiopian Orthodox Church was often associated with Habesha's (Amhara and Tigray ethnic groups from northern Ethiopia) hegemony and Orthodox Christianity was seen as a tool to enhance this hegemony and the serf (gebar) system [2]. Orthodox influence, therefore, remained minimal until Protestant Christianity entered to Amaro in the 1950's.

Meantime, eager to modernize his country, Emperor Haile Selassie I allowed Protestant missions to enter and operate into southwestern Ethiopia in 1920s and 1930s. As a result, three main groups of Protestant missionaries became influential in the 20th century. The Lutheran Mission (which later developed into Ethiopian Mekane Yesus (Place of Jesus) Church, the Baptist Mission (formerly called Sudan Interior Mission (SIM) but later changed to Ethiopian Kale Hiwot-Word of Life) Church, and the Mennonite Mission, which latter developed into two independent churches: Meserete Kirstos (Christ is the Foundation) Church and Mulu Wengel (Full Gospel) Church. The Mennonite Mission entered to Ethiopia as aid agency after World War II. The Baptist/SIM, Kale Hiwot (Word of Life) started active operation in southwestern Ethiopia in the 1920s followed by the Lutheran Mission (Mekane Yesus) at the end of the 1950s [17]. Generally, the first local Charismatic-Pentecostals made their appearance mostly in Addis Ababa in the 1950s and 1960s; however, they rapidly spread to southwestern Ethiopia [17, 21, 24].

Missionaries entered to the Kore country from two directions: in the north to a place called Derba Manana from Wolayta and in the south through Gambo/Burji (the vicinity of Kore in the south). The first group of missionaries to arrive Amaro (through the northern direction) were Kore and Wolayta missionaries. A person named Gorgiso Tijammo was the first Kore convert. Gorgiso lived in a place called Dudane, Gamo country west of Amaro. After attending in a preaching program by Ohmans (an American missionary) in November 1947, Gorgiso went to Derba Menena, northern Amaro, to preach the Gospel [20].

The second group of foreign missionaries to arrive to Burji, south of Kore, were Glen Cain and Albert Brant, members of Baptist (SIM). SIM got permit from the Ethiopian Ministry of Education to establish a school at Gambo (Burji) in April 1947 and went to Burji in November 1948. In April 5, 1950, the SIM missionaries reached Gambo with construction materials. Nevertheless, there was no missionizing activity until two Wolayta preachers appeared in January 1951 [20]. In March 1952, the Wolayta preachers increased to four and to eight in 1954. These preachers also crossed to nearby Kore villages to preach the new religion. The first twelve Kore and Burji converts (amańoch, literally, believers) were officiated in the 1953 baptism at Gambo. During this first baptism two Wolayta elders and one Kore elder (Ato Giorgiso, who lived in Mirab Abaya, Gamo) traveled to Gambo to officiate the converts. The presence of Ato Giorgiso was a big attraction for the Kore. The first bible school opened at Gambo and twenty Burji and Kore young people enrolled in March 1952.
The first mass baptism in Kore took place in November 1954; at this time fifteen people baptized officially. This baptism officially established the first mission church in Kore. Generally, in 1960, there were still only a few mission churches and few coverts [20]. However, although most of the first converts were juniors, the poor, and artisans, religious transformation was already taking place.

The new churches prohibited polygamy, consumption of alcoholic drinks (including local beer called borde and locally distilled strong alcohol called areke) and eating raw meat. More important, however, was the formation of new associations and networks of converts. Named amane mabara (meaning association of converts), these networks and associations reached out all over Kore territory. These associations also started to change the social organization and power structures in Kore; eventually, this new power structures limited the authority of clan heads, Kashaches.

To strengthen and sustain the proselytization, the amane mabara conducted meetings every two months. Contrary to Orthodox Christianity where priests generally have leadership, elected elders were responsible to lead these newly formed churches. Moreover, women and artisans for the first time started to participate in public affairs equally with others. One former tanner and potter $\left(m a n a^{5}\right)$, told me his situation as follows:

Before the amaane [missionaries] came, we did not eat with shawo [ritually 'clean' people]. Even our cattle and the cattle of shawo did not graze together. We did not share a seat. When in road, if a shawo person came across, I had to stop to let him go; otherwise he would insult or even beat me. The maana did not have land; the derg gave us land. It was after the amaane and the $\operatorname{derg}^{6}$ that we started to work with the shawo. After I became amaane, I became equal with the shawo although still there are minor discriminations. Now we are equal before Jesus. (Awoke. Personal comm. with informant. 2013 July 25).

\subsection{The Derg}

In 1974, the Ethiopians revolted against the Ethiopian feudal system and Emperor Haile Selassie I. Nevertheless, the military (the derg) took power and stayed on power until two guerrilla groups drove away it in May 1991. The derg mercilessly suppressed traditional beliefs as 'backward' cultures and 'harmful traditional practices'; it also labelled the Orthodox Christianity as 'false consciousnesses' and suppressed it. The situation was even worse for the Protestants and Charismatic-Pentecostals. When the revolution broke out, most Protestant and Charismatic-Pentecostal churches had mixed feelings about

\footnotetext{
5 The Kore call tanners and potters by the same name, mana.

${ }^{6}$ Derg means 'committee' or 'council' in an old Ethiopic language (Geez). Formed after the1974 revolution, its official name was the Coordinating Committee of the Armed Forces, Police, and Territorial Army. Later they renamed it Provisional Military Administrative Council. It officially embraced the communist ideology in 1975 and remained so until its ousting in 1991.
} 
the revolution. Initially the revolution attracted the evangelical Christians in the peripheral regions of southwestern Ethiopia because they had 'deep socio-economic, political, and religious grievances' [22: $\mathrm{p}$. 14]. Though the initial years of the revolution seemed to favor the Protestant and Charismatic-Pentecostal Christians, this optimism did not last long. Soon the derg labelled all Charismatic-Pentecostals as met' ${ }^{7}$, meaning 'new comer' or 'alien'; the derg publically persecuted and condemned Charismatic-Pentecostal as agents of imperialism. The derg nationalized some Charismatic-Pentecostal churches, their properties, and church schools in 1975. It also prohibited most denominations from undertaking any kind of religious activity in public and imprisoned ministers. Although the churches did not coordinate to respond to this suppression systematically, they did not withdraw from the field. Instead of directly confronting the military regime, they concealed themselves and made unprovocative resistance. On the other hand, they expanded aggressively by directing their activity through clandestine networks of home cells that reached and connected many people [22].

Of course, the derg and Charismatic-Pentecostals were ideological foes; however, they also shared a common interest: that of suppressing traditional cultures and beliefs. In 1975, the derg instituted a campaign called Development through Cooperation Campaign. ${ }^{8}$ The program (actually a campaign) that started in December 1975 mobilized high school and college students and teachers to go to the countryside to spread basic literacy, to reorganize district and village administrative structures and to establish cooperatives throughout the country. Moreover, the campaign students destroyed traditional belief centers, shrines, clan deities, sacred forests and sites in campaign ruthlessly [30]. The suppression of 'backward' cultures and 'harmful' traditional beliefs caused rapid degeneration of traditional beliefs, values, norms, and institutions in Kore and elsewhere in southwestern Ethiopia. This caused vacuum of values, norms and beliefs; Charismatic-Pentecostals used this opportunity to fill in the vacuum and aggressively expand into southwestern Ethiopia.

Moreover, derg's 'one nation' policy stifled political, civil, religious, and economic rights; this engendered many problems that threatened the viability of the Ethiopian state. Generally, although the revolution brought some relief for the peoples of southwestern Ethiopia, the old oppression and subjugation continued under the derg in a similar way. Thus, besides leading to formation of many armed ethnic guerrilla groups, the political oppression also pushed some Charismatic-Pentecostal groups to support the liberation movements [22]. In 1991 two of these guerrilla groups, the

\footnotetext{
${ }^{7}$ In general day to day Amharic conversation, 'Mete' means alien or 'new comer'; this word could be employed for a new fashion, a new way of hair style, language, talking, etc. However, in the context of the Ethiopian Revolution, it used to denote newly introduced or expanding Pentecostal-Charismatic Christianity (or movement) - this usage contrasts with the old and previously known or socially accepted Orthodox, Catholic, and Protestant Christianity.

${ }^{8}$ Officially called, Idiget Behibret Yewuketna Yesira zemacha in Amharic, the campaign was Development through Cooperation Campaign.
}

Tigrian People Liberation Front (TPLF) and the Eritrean People Liberation Front (EPLF), toppled the military regime. As a result Eritrea seceded from Ethiopia and became a new independent African state; on the other hand, Ethiopia formed a new ethnic-based federal state.

\subsection{Post 1991}

The impact of the 1991 government change was multifaceted. The first major change was the new government's lift of restriction on religious activities. This enabled Charismatic-Pentecostals to widen their international interaction and networks and strengthen their position. Due to this, about 30 additional Charismatic-Pentecostal oriented churches came to Ethiopia [17]. In 1960 and 1984, the total number of Charismatic Pentecostals amounted to $1 \%$ of (about 200,000) and $7 \%$ Ethiopia population respectively. This number grew to $11 \%$ in 1994 and 14\% (about 8 million) in 1997. This tremendous 'change was symbolized by the appointment of a Lutheran, Ngasu Gedada as president' of Ethiopia [17: p. 329].

According to the Ethiopian Central Statistical Authority, the four dominant religions in southern Ethiopia in 1994 were Ethiopian Orthodox, Protestant, ${ }^{9}$ Islam, and traditional beliefs with $27.60 \%, 34.80 \%, 16.7 \%$, and $15.4 \%$ respectively [31]. This picture dramatically changes within fifteen years. By 2007 Orthodox, Protestant, Catholic, Islam and traditional belief followers were $19.9 \%, 55.5 \%, 2.4 \%$, $14.1 \%$, and $6.6 \%$ respectively [1]. As the above statistics shows, while followers of the other religions, especially the followers of traditional beliefs are diminishing, the number of the Charismatic-Pentecostals is increasing.

Although currently Charismatic-Pentecostal Christianity is the major social force that shapes the religious as well as political ecology of the Kore, the influence of these missionaries remained minimal until 1991. This was partly due to limited activity of the missionaries (as explained earlier the persecution of the derg was stifling) and partly due to conservatism of the traditional culture. In 1994 Protestant, Ethiopian Orthodox, Catholic, Islam, and traditional belief followers accounted for $52.1 \%, 10.8 \%$, $0.3 \%, 1.0 \%$ and $34.5 \%$ of the Kore population respectively [31]. Charismatic-Pentecostal growth was so rapid that the regional Mekane Yesus Church split into different synods. Accordingly, Amaro district formed its own Mekane Yesus synod in 2009 with followers that amounted to (if what Mekane Yesus claims is true) 96, 040 (61.17\% of the Kore which is 156,983 ) [32]. As I observed from my 2012 visit in Kele, the Kore are now largely Charismatic Pentecostal Christians.

The other major change brought by the new government was reorganization of the country along ethnic lines. The ethnic reorganization of the country had many impacts on the Kore in particular and the people of Ethiopia in general. Before the 1991 government change, many Ethiopians could

\footnotetext{
${ }^{9}$ Protestant in these official statistics included all Protestants, Charismatic and Pentecostals followers.
} 
work and hold government position across the country. However, the ethnic reorganization of the country forced many people, especially civil servants, to return to 'their ethnic homes'. Because of this, Kore teachers and civil servants that lived and worked in different parts of the country, especially in the neighboring Wolayta and Gamo provinces returned to their homeland, to Amaro. The Wolayta and Gamo communities are/were predominantly Charismatic-Pentecostals; therefore, these Kore returnees were mostly Charismatic-Pentecostals. Some of the returnees were preachers and pastors. The entrance of these 'new' Kore immigrants (educated middle class with educational and financial resources by Ethiopian standards) into Amaro gave an élan to the rapid expansion of Charismatic-Pentecostal Christianity in Kore. Robins [4] reported a similar development from the Pacific where educated middle class, who also had financial resources formulate their projects and pursue their visions, took leadership of the Charismatic-Pentecostal movements.

On the other hand, the new government officially demobilized the defeated 'derg army' in May 1991 [33]. Due to this, a large number of the ex-soldiers became homeless and beggars in urban areas. During this miserable time, many ex-soldiers turned to churches for help and support. One demobilized soldier described his conversion story as follows:

Before I went to the army, all my family members were followers of Kore traditional religion. When I returned, my mother was amaane [protestant Christian]. Therefore, she insisted me to go to church and take Jesus. This was a miserable time; sometimes I thought whether God created me like other people. Before I went to the army, I knew Kore God, which was powerful and strong. Now the Kore God is weak to support me and heal my broken heart. In this desperate situation, I accepted my mother's advice and became amaane. On the other hand, the church gave me support; it gave me $25 \mathrm{~kg}$ of wheat per month for three months. This was a big support during those miserable times. It also gave me hope. Many demobilized soldiers converted to amaane during these miserable days. Had it not been for these churches, my life would have been hopeless. Before the government gave me one oxen and food aid, the churches saved my life. I thank my God; I took Yesus and was reborn. Praise be to God (Wontose galata); currently I lead a happy life with my family. Many of my friends died before they were reborn (Awoke. Personal comm. with an ex-soldier. 2013 August 04).

Generally, this feeling is shared by five other demobilized soldiers to whom I talked. The situation was similar to the Nigerian civil war of 1967- 1970 [34], which also provoked the Charismatic-Pentecostal conversion in Nigeria. As one Nigerian Pentecostal pastor explains, after the civil war there was "fear and lack of confidence in the future are becoming the common currency of the day ... We no longer trust anything or anyone ... No jobs, no money, no food, no clothing, no personal dignity." [24: p. 11]

Then, there was also structural adjustment programs (SAPs), which played indirect role for the spread of Charismatic-Pentecostal Christianity. The structural adjustments programs started in the 1980s. These programs were in many ways devastating to many sub-Saharan African countries. Many people lost their jobs when the government privatized and sold public institutions. Governments cut social spending and reduced welfare. Due to these events, real incomes of many people in sub-Saharan Africa dropped as much as $21 \%$ [24]. According to Freeman, "the worsening conditions brought about by these austerity measures led to protests and 'IMF food riots' in many African countries...It was at this time and in this context that the phenomenal growth of NGOs and Pentecostal churches came about.' [24: p. 4) In Ethiopia, the number of NGOs increased from less than 60 in 1980 to 2000 in 2007. World Vision was one of these NGOs whose 'holistic approach was said to include a hidden agenda to encourage Evangelical penetration... World Vision was one of the few NGOs working directly for change of religious affiliation, using $20 \%$ of its budget for Evangelism.' [17: p. 330]

Generally, besides politico-historical factors explained earlier, material gains promised by the Charismatic-Pentecostals and the need for meaning in a changing world are causes for conversion [3]. A prosperity discourse is an appealing feature used by the Charismatic-Pentecostals to attract new people $[35,17,3]$. Prosperity gospel promises economic deliverance from poverty; prosperity gospel advocate the forthcoming abundance of wealth by praying to Jesus, hardworking, and engaging in business. Generally, the sermons of prosperity gospel are often blatantly materialistic [24]. Moreover, as Freeman [24] reports in Gamo, in order to potentiate their gain most Charismatic-Pentecostal churches provide entrepreneurial skills training needed to be employed in public or private organizations or to stimulate people to start private businesses. Most churches also have schools and health centers, all of which attract people.

The Charismatic-Pentecostal use of the media is very important to spread evangelism and to display its 'emblematic ownership of this key symbol of technological modernity' [36: p. 47]. Recorded preaching, church services, and testimonials of individuals are replayed loudly in market and mourning places or other similar public gathering places (including schools). Horns and powerful amplifiers loudly transmit Sunday services and prayers to outside churches. Generally, all these are attractive, especially to people of the rural areas who generally take this as a sign of modernity.

Generally, irrespective of local contexts, some notable features characterize these new churches. They categorically reject any form of traditional belief, ancestral worship and rituals related to these as 'devilish'. They emphasize the Bible and tend to be more ecstatic, emphasizing speaking in the tongues or 'glossolalia', ${ }^{10}$ which is accompanied by

\footnotetext{
${ }^{10}$ Some of my informants told me that there is similarity between spirit possession (tsoze) and ecstatic speaking in the tongue of the
} 
dramatic exorcism of demons from people's bodies [3, 37]. Their emphasis is on moralism and ecstatic prayer. Moreover, the doctrine known as 'Full Gospel' theology has four core elements: Jesus offers salvation, Jesus heals, Jesus is coming again, and Jesus baptizes with the Holy Spirit [24]. They advocate 'complete break with the past', which, according to the advocates, leads to a new 'reborn' personality. This concept of transformation has a deep symbolic meaning. It is a transformation that shows victory over 'traditionalism', over 'backwardness', over evil and 'Satan'. As Freeman argues, 'the key element in this transformation of subjectivity, however, is a shift from seeing oneself as a victim to seeing oneself as a victor.' [24: p.12] This new quality dissociates itself from the local and associates itself with the global 'imagined' Charismatic-Pentecostal community. This delocalization "materializes in widely available (cassette and video) sermons, music, and literature that circulate in global Pentecostal networks and entice the constitution of a new public of born again believers with a strong global outlook." [35: p. 461]

The 'make a complete break with the past' and the 'rapture' [37] of Charismatic-Pentecostal Christianity takes many forms, such as ignoring Kore traditional work parties such as kelle, ${ }^{11}$ hayle, ${ }^{12}$ urre, ${ }^{13}$ etc., wonoba ${ }^{14}$ as 'backward' cultural practices. Thus, because of misinterpretation and misunderstanding of cultural practices, these important traditional institutions are either ignored or left to disintegrate without replacement. In general, there is a tendency in many African countries of equating Protestantism with modernism, economic progress, and deepening of political culture. Charismatic-Pentecostalism uses a temporalizing rhetoric and strategy; it represents traditions as 'a matter of the past' although peoples' present and past are intertwined and dynamic [35].

If converted people pray for their ancestors or spirits, Charismatic-Pentecostals say that these people have relapsed to the past because Satan has corrupted them. However, life as the local people live is not temporally divided as past and present. The impacts of the expansion of Charismatic-Pentecostal Christianity are inevitable, but 'complete break with the past' is not fully viable. For example, kinship structures still decide marriage arrangements and inheritance, especially inheritance of land. Although the impact of Charismatic-Pentecostal Christianity is tremendous in enhancing people's personal choice and changing traditional practices such as polygamy, many other practices and traditional values that oppose the teachings of

Charismatic-Pentecostals; many individuals who speak in tongues used to have possession spirits or there was possession spirits in their family. May be there is structural similarity between the two and this might have facilitated the rapid spread of Charismatic-Pentecostal Christianity that emphasize ecstatic speaking in the tongue.

${ }_{11}$ Kele is exchange of labor without food.

12 Hayle is labor exchange accompanied by food and drink service; it is mostly practiced during plowing and harvest season.

${ }^{13}$ Urre is continuous labor service for big house construction; at the end of the house construction, the owner makes a feast by killing from three to six big oxen for the people who constructed the house.

${ }_{14}$ Wonoba is exchange labor service, especially during sowing season, without food; it is mostly practiced in the highlands.
Christianity are still there. For example, while every Christian Kore believes, at least in principle, God created all men equally in His image still there is no marriage between the artisans and the non-artisan (farmers).

\section{Conclusions}

This paper set out to investigate the rapid expansion of Charismatic-Pentecostal Christianity in Kore as a counter-hegemonic reaction capable of reorganizing the Kore culture and belief. Politico-historical reasons had been at the base of the introduction and expansion of Protestant missions and Charismatic-Pentecostal Christianity in Kore and southwestern Ethiopia.

The entrance of missionaries to southwestern Ethiopia was a political decision by Emperor Haile Selassie I who invited the missionaries to 'modernize' his country. In northern Ethiopia, political legitimacy came from the central government and the Orthodox Church [38]. This was incompatible with the Kore social system (and the social systems of the peoples' southwestern Ethiopia) where religious dignitaries, who themselves represented clan or tribal deities, entrusted legitimacy to political leaders. Because the traditional power structure, the cultural, and belief system of the Kore and the people of southwestern Ethiopia were generally against the unifying motive of the emperor, it was necessary to destroy these and undermine the political legitimacy and power of local chiefs. On the other hand, the Ethiopian Orthodox Church did not have the necessary infrastructure, personnel, and logistics to rapidly convert the Kore into Orthodox Christianity. Nevertheless, even if the Ethiopian Orthodox Church had the capacity, personnel, and infrastructure to do this, there was a politico-historical problem: the Kore and the peoples of southwestern Ethiopia were not willing to accept the teachings of Ethiopian Orthodox Christianity because they saw Ethiopian Orthodox Christianity as extension of the Ethiopian State that subjugated and oppressed them. Therefore, the Emperor's decision in inviting European missionaries and supporting them to convert the peoples of southwestern Ethiopia to Protestant Christianity was a wise political move.

Although technological, education, and other socio-economic conditions played significant roles for mass conversion of the Kore (and the peoples of southwestern Ethiopia) to Charismatic-Pentecostal Christianity, the major reason behind mass conversion is a rejection and counter-hegemonic reaction to the oppressive Ethiopian state and the Ethiopian Orthodox Christianity. In other words, mass conversion to Charismatic-Pentecostal Christianity is not only about spiritual or economic advantages; it is also about personal and ethnic dignity, a dignity suppressed by the Ethiopian state and Orthodox Christianity.

On the other hand, the rapid expansion of Charismatic-Pentecostal Christianity also represents 'a paradigm case of a global cultural flow that starts historically 
in the West and expands to cover the globe' [4: p.118]. Generally, due to this global cultural flow, the Kore and the people of southwestern Ethiopia are becoming part of 'imagined' global community of Charismatic-Pentecostal Christians yet keeping their local identity.

Eventually, this religious transformation is restructuring the religious landscape of Ethiopia in a new form; threesome religious landscape seems to be forming in Ethiopia: consolidation of and continued dominance of Ethiopian Orthodox Christianity in central-northern Ethiopia, dominance of Charismatic-Pentecostal Christianity in southwestern Ethiopia, and dominance of Islam in northeastern, eastern, and parts of western Ethiopia. These developments beget one crucial question: is the religious reorganization of the national religious space in Ethiopia creating another fault-line for political conflict/rivalry between southwestern, eastern, and northern Ethiopia? May or may not be; this calls for further investigation.

\section{REFERENCES}

[1] Central Statistical Authority (CSA). Summary and statistical report of the 2007 population and housing census: population size by age and sex. Addis Ababa: Federal Democratic Republic of Ethiopia; 2008.

[2] Awoke Amzaye Assoma. The Kore of Amaro: a historical survey. BA thesis. Addis Ababa: Addis Ababa University; 1985

[3] Keller, E. The road to clarity Seventh Day Adventistism in Madagascar. New York: Palgrave Macmillan; 2005.

[4] Robbins, J. The globalization of Pentecostal and charismatic Christianity. Annual Rev of Anth. 2004; 117-143.

[5] Cerulli E. Peoples of southwestern Ethiopia and its borderland. London: International African Institute; 1956

[6] Haberland, E. The influence of Christian empire on southern Ethiopia'. J of Semitic Studies. 1964; 9 (1).

[7] Huntingford, G. W. B. The Galla of Ethiopia: the kingdoms of Kafa and Janjero. London: International African Institute; 1955.

[8] Levine, Donald N. Ethiopia: the evolution of a multi-ethnic society. London: the University of Chicago Press; 1974.

[9] Bender, Marvin Lionel, ed. The non-Semitic languages of Ethiopia. Vol. 5. African Studies Center. East Lansing: Michigan State University; 1976.

[10] Fleming, Harold C., and Marvin L. Bender (eds). Non-Semitic languages. In: Bender, Marvin Lionel, J. Donald Bowen, Robert L. Cooper, and Charles A. Ferguson (eds), Languages in Ethiopia. London: Oxford University Press; 1976.

[11] Donham, Donald L., and Wendy James (eds). The Southern marches of imperial Ethiopia: essays in history and social anthropology. Cambridge: Cambridge University Press; 1986.
[12] Donham, Donald L. Marxist modern: an ethnographic history of the Ethiopian revolution. Berkley, CA/Oxford: University of California Press/James Currey; 1999.

[13] Sato, R. Evangelical Christianity and ethnic consciousness in Majangir. In: Donald L. Donham, E. Kurimoto, and A. Triulzi (eds), Remapping Ethiopia: socialism and after. Oxford: James Curry Ltd; 2002.

[14] Kaplan, S. Dominance and diversity: kingship, ethnicity, and Christianity in Orthodox Ethiopia'. CHRC. 2009; 89 (1-3): 291-3-5.

[15] Bønne, F. Christianity in the dynamics of south Ethiopian societies and cultures: Kambbaata-Hadiiyya'. ICES: Internat. Conf. of Eth Studies. 1997; 3: 3-133.

[16] Abbink, J. Religion in public spaces: emerging Muslim-Christian polemics in Ethiopia. African Affairs. 2011; 110 (439): 253-274.

[17] Persoon, J. New Perspectives on Ethiopian and African Christianity: Communalities and Contrasts in the Twentieth Century Religious Experience. Exchange. 2005; 34(4): 306-336.

[18] Getatchew Haile, Lande Aasulv, and Samuel Rubenson. The missionary factor in Ethiopia. Peter Lang: Frankfurt; 1998.

[19] Eide, Øyvind M. Political dynamics in the wake of missionary efforts within the realm of human rights: the case of Ethiopia'. SMT Swedish Missiological Themes. Svennsk: Missiolnstidskrift. 2001; 89 (4).

[20] Balisky, E. P. Walitata evangelists: a study of religious innovation in southern Ethiopia, 1937-1975. American Society of Missiology Monograph Series, Number 6. Eugene, Oregon: Pickwick Publications; 2009.

[21] Tibebe Eshete. The Sudan Interior Mission (SIM) in Ethiopia (1928-1970)'. NE Afr Studies 1999; 6 (3): 27-57.

[22] Tibebe Eshete. Evangelical Christians and indirect resistance to religious persecution in Ethiopia. The Rev of Faith \& Internat Affairs. 2010; 8 (1): 13-21.

[23] Donham, Donald L. The promise of 1991: reshaping the future and the past: introduction. In: Wendy James, Donald L. Donham, Eisei Kurimoto, and Alessandro Triulzi (eds), Remapping Ethiopia: socialism and after. Oxford: James Currey. 2002; 151-154.

[24] Freeman, D. The Pentecostal ethic and the spirit of development. In: Dena Freeman (ed), Pentecostalism and development: churches, NGOs and social change in Africa. London: Palgrave Macmillan; 2012.

[25] Girma, MA. Clash of ideologies and survival of evangelical movement in Ethiopia. $\mathrm{J}$ for the Study of Religions and Ideologies. 2011; 10 (30): 390-396.

[26] Data Dea. Christianity and spirit mediums: experiencing post-socialist religious freedom in southern Ethiopia. Max Planck Institute for Social Anthropology Working Paper, No. 75. Sale: Max Planck Institute; 2005.

[27] Pankhurst, R. The Ethiopian borderlands: essays in regional history from ancient times to the end of the 18th century. The Red Sea Press; 1997.

[28] Erlich, H. Islam and Christianity in the Horn of Africa: Somalia, Ethiopia, Sudan. Lynne: Rienner Publishers; 2010. 
[29] Awoke Amzaye Assoma. Profile of mosaic cultures and peoples of Southern Nations, Nationalities and Peoples' Regional State. Awassa: Bureau of Information and Culture; 2007.

[30] Aalen, L. The politics of ethnicity in Ethiopia: actors, power and mobilization under ethnic federalism. Leiden: Kninklijke Brill; 2001.

[31] Central Statistical Authority (CSA). The 1994 population and housing census of Ethiopia: results for Southern Nations, Nationalities, and Peoples' Region, Volume II analytical report. Addis Ababa: Federal Democratic Republic of Ethiopia; 1998.

[32] Negeri, W. I. Mekane Yesus International Mission Society (MYIMS): An overview of the Mission work of the EECMY. The Ethiopia network Annual Conference. Pittsburg; April 2010.

[33] Dercon, S. and Daniel A. 'Where have all the soldiers gone: demobilization and reintegration in Ethiopia'. World Development. 1998; 26(9): 1661-1675.
[34] Falola, T (ed.) (2005) Christianity and social change in Africa: essays in honor of J. D. Y. Peel. Durham: Carolina Academic Press.

[35] Meyer, B. Christianity in Africa: From African independent to Pentecostal-charismatic churches. Annual Review of Anthropology. 2004; 447-474.

[36] Lewiston, E. Pentecostal power and the holy spirit of capitalism: re-territorialization in the charismatic cosmology. The Graduate Student Journal of the Department for the Study of Religion at the University of Toronto. 2011; vol. 3.

[37] Meyer, B. 'Make a complete break with the past': memory and post-colonial modernity in Ghanaian Pentecostalist discourse'. Journal of Religion in Africa. 1998; 28 (3): 316-349.

[38] Shack, William A. Some aspects of ecology and social structure in the Ensete complex in south-west Ethiopia. Journal of the Royal Anthropological Institute of Great Britain and Ireland. 1963; 93: 72-79. 